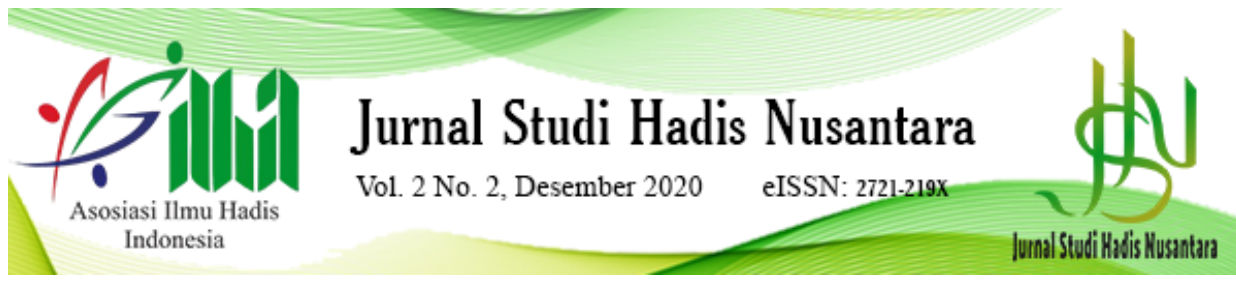

\title{
MANAJEMEN DOMESTIK RUMAH TANGGA WANITA MUSLIMAH DALAM AJARAN SUNNAH
}

\author{
Jannah Lukman \\ IAIN Takengon \\ jan22nah@gmail.com
}

\begin{abstract}
Muslim women couldn't be separated essentially with domestic household affairs. Definitely, this matter has not gone unnoticed by the Hadith that touches all of the part of muslim life. Muslim women also have a role as the leaders in domestic affairs and will be held accountable in the hereafter. This study is here to explain how the Sunnah has guided muslim women long time ago to be successful in domestic household affairs. This study also aimed to detail the Hadiths related to the domestic principles of muslim women households. This study used the thematic Hadith study method to focus and discover the basic concepts of domestic muslim women household management that already exist in the teachings of the Sunnah. After doing research, it was found that there are as many twenty Hadiths related to this matter. This study also found the basis for domestic management of muslim women households consists of: love to take care of the household; serving husbands and caring for children; keep the bathroom; tidying up the kitchen; prevent animal nests in the house; dress up for husband, obey him and support him; tidying up the lights before going to bed at night; decorate the room of the house; keep the husband from being attracted to other women; ask permission when leaving the house; willing to breed a lot. It is hoped that this study will add to the wealth of knowledge for muslim women to remain cheerful and successful in managing domestic and household affairs.
\end{abstract}

Keywords: Muslim women, the teaching of the Sunnah, househould

\begin{abstract}
Abstrak
Pada fitrahnya, wanita muslimah tidak dapat terlepas dari urusan domestik rumah tangga. Tentu saja hal ini tidak luput dari aspek kajian Hadis yang memang menyentuh segala sendi kehidupan seorang muslimah. Wanita muslimah juga memiliki peranan sebagai pemimpin dalam urusan domestik rumah tangga dan akan dimintai pertanggungjawabannya di akhirat kelak. Kajian ini hadir untuk menjelaskan bagaimana Sunnah telah jauh hari membimbing muslimah agar sukses dalam urusan domestik rumah tangga. Kajian ini juga bertujuan merinci Hadis-hadis
\end{abstract}


yang berhubungan dengan prinsip manajemen rumah tangga muslimah. Kajian ini menggunakan metode kajian Hadis tematik untuk memfokuskan dan menemukan konsep dasar manajemen rumah tangga muslimah yang telah ada dalam ajaran Sunnah. Setelah mengkaji didapati bahwa ada sebanyak dua puluh Hadis yang berhubungan dengan perkara tersebut. Kajian ini juga mendapati bahwa prinsip dasar manajemen rumah tangga muslimah meliputi: mencintai mengurus rumah tangga; melayani suami dengan menjadi bidadari di rumahnya; merawat anak-anak dengan baik; menjaga kebersihan kamar mandi dan ruangan di rumah; mengurus kainkain yang kotor; membereskan dapur; mengatur menu makanan yang baik; mencegah adanya sarang binatang yang merusak rumah; berdandan untuk suami, patuh padanya dan mendukungnya; membereskan lampu tidur; mendekorasi ruangan rumah; menjaga agar suami tidak tertarik dengan wanita lain; meminta izin jika keluar rumah dan bersedia untuk berketurunan yang banyak. Kajian ini diharapkan menambah khazanah ilmu bagi para muslimah agar tetap ceria dan sukses dalam manajemen rumah tangga.

Kata Kunci: pengangkatan, kepala negara, hadis

\section{PENDAHULUAN}

Dalam perjalanannya kata rumah tangga memiliki arti yang meluas jika disandingkan dengan kata yang lain. Dalam Kamus Bahasa Indonesia, manajemen berarti proses pemakaian sumber daya secara efektif untuk mencapai sasaran yang telah ditentukan atau penggunaan sumber daya secara efektif untuk mencapai sasaran. Manajer berarti orang yang memimpin dan mengatur pekerjaan di bidangnya serta yang berwenang dan bertanggung jawab membuat rencana dan mengendalikan pelaksanaannya hingga mencapai target yang telah ditetapkan. ${ }^{1}$

Sedangkan kata domestik berarti dalam negeri atau mengenai (bersifat) rumah tangga atau binatang peliharaan atau binatang jinak. ${ }^{2}$ Kata rumah sendiri berarti bangunan untuk tempat tinggal. ${ }^{3}$ Bila disandingkan dengan kata lain, kata rumah juga dipakai untuk kata yang kiasan ${ }^{4}$ atau kata majemuk. ${ }^{5}$ Sedangkan kata rumah tangga dalam perjalanannya memiliki arti yang meluas jika disandingkan dengan kata lain. Adapun kata rumah tangga berarti segala sesuatu yang berhubungan dengan urusan kehidupan 1 Pusat Bahasa, Kamus Bahasa Indonesia, (Jakarta: Pusat Bahasa Departemen Pendidikan Nasional, 2008), hlm. 909-910

2 Ibid., hlm. 362

3 Ibid., hlm. 1226

4 Contohnya kata rumah gedang versendi perak yaitu bangsawan lagi kaya; atau rumah gedang ketirisan yaitu istri yang tidak mendatangkan bahagia kepada suami. Ibid., hlm. 1227

5 Contohnya kata rumah api yaitu menara api atau mercu suar; atau rumah asap yaitu rumah untuk mengasapi karet lembaran agar menjadi kering. Ibid., hlm. 1227 
dalam rumah atau segala sesuatu yang berhubungan atau berkenaan dengan keluarganya. Adapun berumah tangga berarti berkeluarga. ${ }^{6} \mathrm{Jadi}$, kehidupan rumah tangga tidak terlepas dari interaksi antara suami dan istri. Sedangkan ibu rumah tangga berarti wanita yang mengatur penyelenggaraan berbagai macam pekerjaan rumah tangga. ${ }^{7}$

Berdasarkan pengertian di atas, manejemen domestik rumah tangga dapat diartikan sebagai proses optimalisasi pengaturan urusan internal kehidupan rumah tangga dan yang berhubungan dengan keluarga untuk mencapai kebahagiaan setiap anggota keluarga.

Dalam Islam, keterangan tentang interaksi pasangan suami istri digambarkan dengan sangat harmoni dan indah. Sebagaimana firman Allah SWT.,

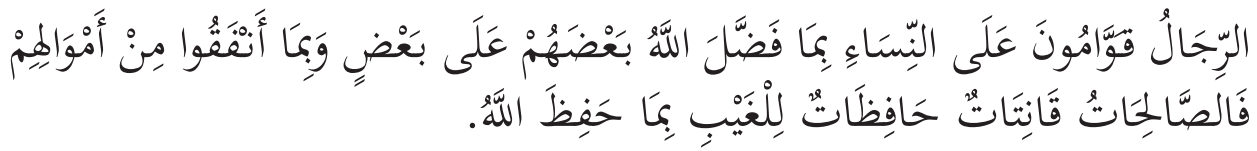

"Laki-laki adalah pemimpin bagi wanita dengan apa yang telah Allah karuniakan bagi sebagian mereka atas sebagian yang lain dan karena apa yang telah mereka (laki-laki) nafkahkan dari harta-harta mereka, maka wanita-wanita yang baik adalah yang taat dan menjaga diri ketika suaminya tiada." (QS. An-Nisa': 34)

Dalam rumah tangga Islam, pasangan suami dan istri adalah teman hidup yang masing-masing memiliki peran tersendiri. Menurut ayat di atas, seorang suami adalah qawwam yaitu pemimpin dan pelindung bagi keluarga dan kedudukannya lebih tinggi dari istri karena karunia Allah dan nafkah yang telah diberikannya pada istri. Sedangkan kedudukan istri di bawah kepemimpinan suaminya dan dituntut untuk taat pada suami dan menjaga kehormatan dirinya. Hal ini karena akad suci pernikahan menjadikan wanita muslimah lebih terjaga agama dan kehormatannya.

Selain itu dinyatakan di dalam Hadis bahwa suami dan istri memiliki tanggung jawab masing-masing dan akan dimintai pertanggungjawaban tentang tugas masing-masing di akhirat kelak apakah dapat dikerjakan dengan baik atau terbengkalai. Rasulullah SAW bersabda,

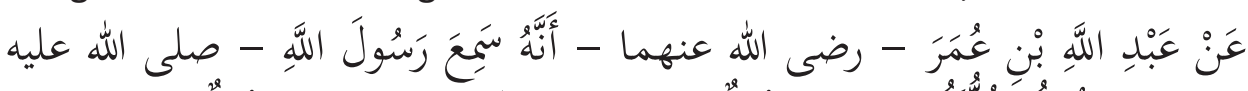

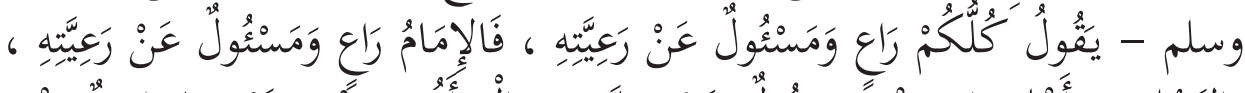

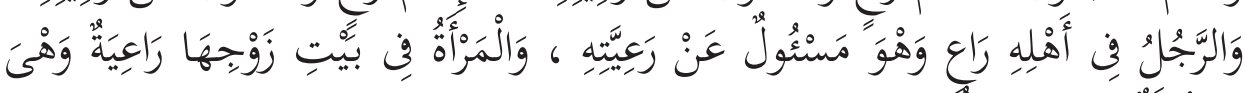

6 Ibid., hlm. 1228

7 Ibid., hlm. 537 
Dari 'Abdullah bin Mas'ud, radiyallahu 'anhuma, bahwa beliau mendengar Rasulullah sallallahu 'alaihi wa sallam bersabda, "Setiap kalian adalah pemimpin dan akan ditanya tentang yang dipimpinnya, imam adalah pemimpin dan akan ditanya tentang yang dipimpinnya, laki-laki di keluarganya adalah pemimpin dan akan ditanya tentang yang dipimpinnya, seorang wanita di rumah suaminya adalah pemimpin dan dia ditanya tentang yang dipimpinnya." (HR. Bukhari, Muslim dan Abu Daud).

Hadis ini menunjukkan bahwa ternyata urusan domestik rumah tangga berada di bawah kendali dan tanggung jawab istri meskipun hal tersebut dapat dilakukannya sendiri atau didelegasikan pada asisten rumah tangga. Oleh karena itu perkara ini adalah di bawah pengawasan istri sehingga suami dapat fokus untuk mencari nafkah.

Jika tanggung jawab mengurus rumah tangga ini disyariatkan tentunya Islam membimbing agar urusan tersebut dapat dijalankan dengan baik. Oleh karena itu, pasti dapat ditemukan dalil-dalil dari Sunnah yang mendukung motivasi melakukan kebaikan dalam mengurus rumah tangga khususnya bagi wanita muslimah. Adakah dalil yang berkaitan dengan hal tersebut di dalam Sunnah? Bagaimana prinsip dasar bagi wanita muslimah untuk mengatur rumah tangganya dengan baik? Kajian ini hadir untuk menelusuri dan mengupas hal-hal yang berkaitan dengan mengurus rumah tangga sesuai dengan ajaran Sunnah untuk memudahkan wanita muslimah agar dapat menjalankan tugasnya dengan senang hati dan sukses tanpa merasa terbebani. Hal ini karena mengatur rumah tangga adalah sebuah rutinitas yang tidak kenal lelah dan tanpa habisnya.

Jika tanggung jawab mengurus rumah tangga ini disyariatkan tentunya Islam membimbing agar urusan tersebut dapat dijalankan dengan baik. Oleh karena itu, pasti dapat ditemukan dalil-dalil dari Sunnah yang mendukung motivasi melakukan kebaikan dalam mengurus rumah tangga khususnya bagi wanita muslimah. Adakah dalil yang berkaitan dengan hal tersebut di dalam Sunnah? Bagaimana prinsip dasar bagi wanita muslimah untuk mengatur rumah tangganya dengan baik? Kajian ini hadir untuk menelusuri dan mengupas hal-hal yang berkaitan dengan mengurus rumah tangga sesuai dengan ajaran Sunnah untuk memudahkan wanita muslimah agar dapat menjalankan tugasnya dengan senang hati dan sukses tanpa merasa terbebani. Hal ini karena mengatur rumah tangga adalah sebuah rutinitas yang tidak kenal lelah dan tanpa habisnya.

Belakangan urusan tentang rumah tangga ini menjadi berkembang dengan hadirnya ilmu yang berhubungan dengan gender dan manajemen 
interior dan dekorasi rumah sehingga masyarakat modern lebih mudah menyerap informasi terkait dengan hal ini.

Peran istri dalam masyarakat Indonesia khususnya Pulau Jawa masih dianggap secara tradisional dengan istilah kanca winking, yaitu menggambarkan peran istri dalam sektor domestik. Kanca wingking sendiri berarti teman belakang, yaitu sebagai teman dalam mengelola urusan rumah tangga, khususnya urusan anak, memasak, mencuci dan lain-lain atau lebih sering dikenal dengan masak, mancak, manak. Istilah lain yang melekat pada diri seorang perempuan atau istri yakni dapur, pupur, kasur, sumur. ${ }^{8}$

Di sisi lain, status sebagai ibu rumah tangga pun telah dikaji apakah sebagai pekerjaan atau aktifitas karena statusnya dibahas berdasarkan berpenghasilan atau tidak. Ternyata jika dinilai dari sudut ekonomi sebagai sebuah standar untuk men-streotype harga yang harus dibayar bagi orang yang mampu mengatur rumah dan selalu memberikan kenyamanan yang berhubungan dengan kebersihan, keteraturan, dan kedamaian yang berhubungan dengan suasana jiwa dan batin dalam rumah adalah sangat tinggi dan tak ternilai. Hal ini karena peran yang dilakoni oleh ibu rumah tangga sangat banyak yaitu: babysitter, perawat, koki, akuntan, dokter, psikolog, guru, stylist, bodyguard, sekretaris, sopir, manajer. Bila dibayangkan untuk besaran gaji atau upah minimum satu profesi saja dalam jam kerja pukul 8.00 pagi sampai dengan pukul 16.00 itu dibayar sekitar dua juta Rupiah per bulan selain uang lembur jika ada. Jadi, pemahaman bahwa ibu rumah tangga selalu diidentikkan dalam ranah domestik yang tidak menghasilkan nilai ekonomi perlu dipertimbangkan kembali. ${ }^{9}$

Selanjutnya, di bidang desain interior, seorang desainer dituntut mampu menafsir keinginan pengguna tanpa harus pengguna menyampaikan keinginan secara detail terkait seleranya. Hal ini secara teoritis dapat dipelajari dan selanjutnya dapat dirumuskan secara kreatif. ${ }^{10}$ Sementara itu bidang desain interior telah berkembang lagi menjadi dekorasi interior dan keduanya terdapat perbedaan. Dekorasi interior secara umum terkait dengan sesuatu yang menyangkut finishing (pengecatan, pelapisan), pengolahan permukaan, penataan perabot dan pelapisan dinding. Dekorasi tidak secara khusus memperhatikan interaksi dan kebiasaan manusia. Untuk profesi 8 Dyah Purbasari Kusumaning Putri and Sri Lestari, "Pembagian Peran Dalam Rumah Tangga Pada Pasangan Suami Istri Jawa," Jurnal Penelitian Humaniora 16, no. 1 (2015): 72-85, http://journals.ums.ac.id/index.php/humaniora/article/view/1523/1056.

9 Heri Junaidi, “Ibu Rumah Tangga: Streotype Perempuan Pengangguran,” An Nisa'a 12, no. 1

(2017): 77-88.

10 Sunarmi, "Pendekatan Pemecahan Desain Interior Rumah Tinggal," ORNAMEN 10, no. No. 1 (2013): 41-56. 
dekorator interior, tidak adanya persyaratan perizinan maupun pendidikan formal di bidang dekorasi interior, maka siapa saja dapat menjadi dekorator interior. ${ }^{11}$ Di sisi lain, biasanya ibu rumah tangga berperan dalam pemilihan dan penataan perabot di rumahnya.

Adapun kajian yang penulis lakukan membahas tentang manajemen dasar urusan domestik rumah tangga wanita muslimah yang dikaji berdasarkan ajaran Sunnah. Kajian ini membahas peranan wanita muslimah mengurus dalaman rumah tangga yang sesuai dengan ajaran Sunnah. Kajian ini diharapkan akan menambah kajian ilmiah tentang keunggulan ajaran Islam yang menyentuh segala aspek kehidupan umatnya. Kajian ini juga diharapkan dapat menunjukkan bahwa pekerjaan apapun itu jika ada landasan syariat-Nya dan dilakukan karena Allah akan memiliki kedudukan yang sangat mulia.

\section{METODE PENELITIAN}

Kajian ini menggunakan metode kepustakaan. Dalam mengumpulkan data, kajian ini mengambil data primer dari Kitab-kitab Sumber Utama, jurnal dan buku-buku yang berhubungan dengan kajian ini. Pada kajian ini penulis menggunakan metode Hadis tematik dimana penulis mengumpulkan Hadis-hadis yang berkaitan dengan manajemen domestik rumah tangga untuk wanita muslimah. Kajian ini mengumpulkan bagaimana istri-istri Rasulullah mengurus rumah tangganya. Untuk memudahkan pencarian, penulis hanya menelusuri Hadis-hadis yang derajatnya sahih dengan metode takhrij Hadis dengan menggunakan Maktabah Syamilah.

Dalam menganalisis data hasil kajian, penulis menggunakan metode analisis deskriptif. Setelah Hadis-hadis yang berkaitan dikumpulkan, kajian ini meneliti aspek yang bersentuhan dengan manajemen domestik rumah tangga wanita muslimah agar diketahui konsep dasar yang berkaitan dengan hal-hal yang berada di bawah pengawasan wanita muslimah di rumah. Dengan demikian dapat ditemukan konsep dasar panduan wanita muslimah untuk mengontrol dan mengatur urusan domestik rumah tangga sesuai dengan ajaran Sunnah. Selanjutnya untuk menjelaskan Hadis-hadis yang berkaitan dengan urusan domestik rumah tangga wanita muslimah, kajian ini juga merujuk kepada kitab-kitab penjelasan Hadis (kutub syuruh al-Hadith) jika ada istilah yang memerlukan penjelasan dan juga membandingkannya dengan keadaan saat ini.

11 Dwi Retno Sri Ambarwati, “Antara Desain Interior Dan Dekorasi Interior Sebuah Kajian Komparatif," LINTAS RUANG: Jurnal Pengetahuan \& Perancangan Desain Interior 2, no. 3 (2012). 


\section{HASIL DAN PEMBAHASAN}

Setelah melakukan penelusuran Hadis dalam Kitab-kitab hadis Sumber Utama, kajian ini menemukan Hadis hadis yang berkaitan dengan manajemen mengurus rumah tangga ada sebanyak 20 Hadis. Sebagai gambaran jumlah Hadis yang berhubungan dengan rumah tangga dapat dilihat pada tabel teks Hadis di bawah ini.

\begin{tabular}{|c|c|c|c|}
\hline No. & Awal Teks Hadis & Derajat Hadis & Riwayat \\
\hline 1 & 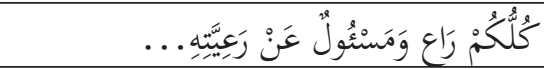 & Sahih & $\begin{array}{l}\text { Bukhari, Muslim } \\
\text { dan Abu Daud }\end{array}$ \\
\hline 2 & 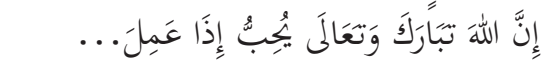 & Sahih & $\begin{array}{l}\text { At-Tabrani dan Al- } \\
\text { Baihaqi }\end{array}$ \\
\hline 3 & فِاشه فَأََتَتْْ .... & Sahih & Bukhari \\
\hline 4 & 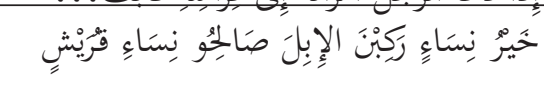 & Sahih & $\begin{array}{l}\text { Bukhari, Muslim } \\
\text { dan Ahmad }\end{array}$ \\
\hline 5 & أَكْثْته عَنَ & Sahih & Al-Hakim \\
\hline 6 & 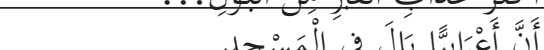 & Sahih & Muslim \\
\hline 7 & 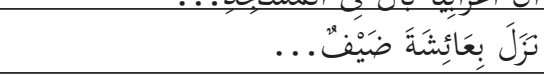 & Sahih & $\begin{array}{l}\text { At-Tírmizi, Ibnu } \\
\text { Majah dan Ahmad }\end{array}$ \\
\hline 8 & أَنَّهَا أَتَتْت رَسُولَ اللَّهِ -صلى الله عليه وسلم- & Sahih & Muslim \\
\hline 9 & 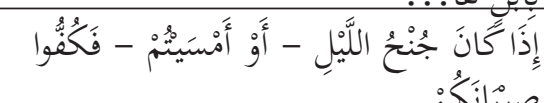 & Sahih & $\begin{array}{l}\text { Bukhari, Muslim, } \\
\text { At-Tirmizi }\end{array}$ \\
\hline 10 & 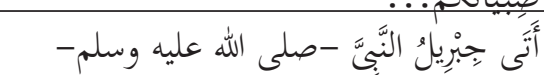 & Sahih & Muslim \\
\hline 11 & كَانَ النَّقٌُ كَانَ النَّبٌُ صلى الله عليه وسلم & Sahih & Al-Hakim \\
\hline 12 & צ: & Hasan & Abu Daud \\
\hline 13 & 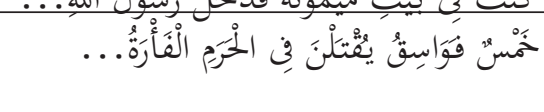 & Sahih & $\begin{array}{l}\text { Bukhari, Muslim, } \\
\text { Abu Daud dan At- } \\
\text { Tirmizi }\end{array}$ \\
\hline 14 & خَيْرُ النِّسَاءِ مَنْ تُسِرُ إِذَا نُظِرَ ... & Sahih & $\begin{array}{l}\text { Al-Hakim, An- } \\
\text { Nasa'i, At-Tabrani } \\
\text { dan Abi Hatim }\end{array}$ \\
\hline 15 & 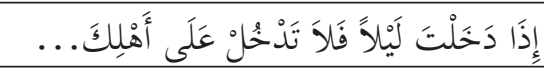 & Sahih & $\begin{array}{l}\text { Bukhari, An- } \\
\text { Nasa'i. Ahmad }\end{array}$ \\
\hline 16 & عَشْرُ مِنَ الْفِطرَة ... & Sahih & $\begin{array}{l}\text { Muslim, Abu } \\
\text { Daud, At-Tirmizi, } \\
\text { Ibnu Majah, } \\
\text { Ahmad }\end{array}$ \\
\hline 17 & 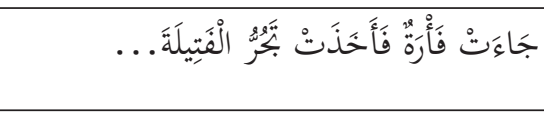 & Sahih & $\begin{array}{l}\text { Abu Daud, Al- } \\
\text { Hakim, Al-Baihaqi } \\
\text { dan Ibnu Hibban }\end{array}$ \\
\hline 18 & 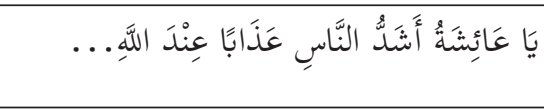 & Sahih & $\begin{array}{c}\text { Bukhari,Muslim } \\
\text { Abu Daud dan } \\
\text { Ahmad }\end{array}$ \\
\hline
\end{tabular}




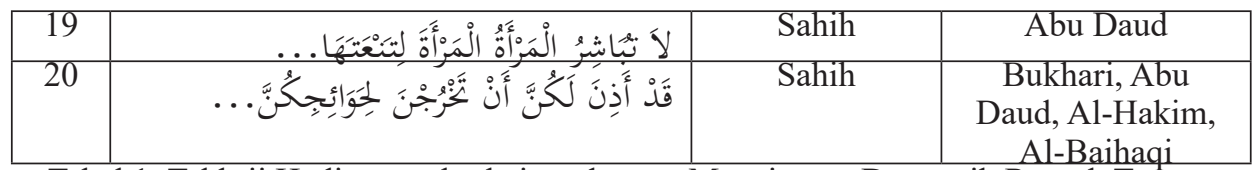

Tabel 1. Takhrij Hadis yang berkaitan dengan Manajemen Domestik Rumah Tangga

Setelah menelaah dua puluh Hadis di atas, kajian ini menemukan ada empat belas prinsip dasar manajemen domestik rumah tangga wanita muslimah sesuai ajaran Sunnah. Prinsip-prinsip ini akan dijelaskan sebagai langkah-langkah yang harus ditempuh untuk sukses mengatur urusan domestik rumah tangga, yaitu sebagai berikut:

\section{Mencintai mengurus rumah tangga}

Rasulullah sallallahu 'alaihi wa sallam bersabda tentang ketekunan:

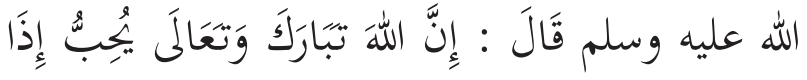

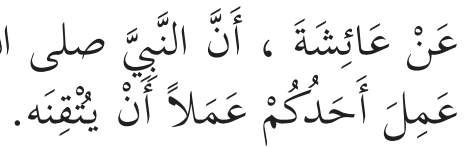

Dari 'Aisyah bahwasanya Nabi SAW bersabda, "Sungguh Allah tabaraka wa ta 'al'a sangat senang apabila seseorang di antara kalian melakukan sesuatu amalan dia melakukannya dengan tekun." (HR. At-Tabrani da AlBaihaqi)

Tekun berasal dari Bahasa Arab atqana yang berarti ahkama atau menjalankan. Laki-laki yang tekun disebut mutqin. ${ }^{12}$ Tekun artinya berusaha menjalankan dengan sungguh-sungguh. Tekun juga berarti sungguhsungguh dengan cara mencintai pekerjaan yang dilakukan sehingga akan berusaha mencapai hasil yang sebaik-baiknya. Tekun adalah kesungguhan hati. Hati menjadi landasan energi bagi seseorang individu untuk beramal. Oleh karena itu, wanita muslimah semestinya mencintai pekerjaan mengurus rumah tangga. Ditambah lagi hal ini adalah sebuah rutinitas yang memang selalu harus di bawah kontrolnya sehingga memerlukan ketekunan.

Selain itu, sesuatu yang dikerjakan dengan senang hati akan terasa ringan. Hadis ini juga mengandung pengertian bahwa cinta Allah menunggu bagi wanita muslimah yang tekun dalam menyempurnakan urusannya. Selain itu, urusan di dalam rumah tangga ini juga akan dimintai pertanggungjawaban di akhirat nanti. Sebagaimana Hadis di atas bahwa Rasulullah bersabda:

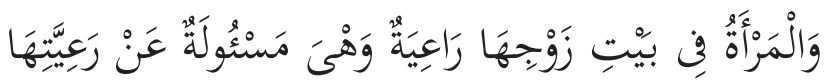

Yang artinya, "Dan wanita di rumah suaminya adalah pemimpin dan dia

12 Majma'al-Lughah al-'Arabiyyah, Al-Mu'jam al-Wajiz, (Republik Arab Mesir: Kementerian Pendidikan dan Pengajaran, 2003), hlm. 76 
akan ditanya tentang kepemimpinannya."

\section{Melayani suami dengan menjadi bidadari di rumahnya}

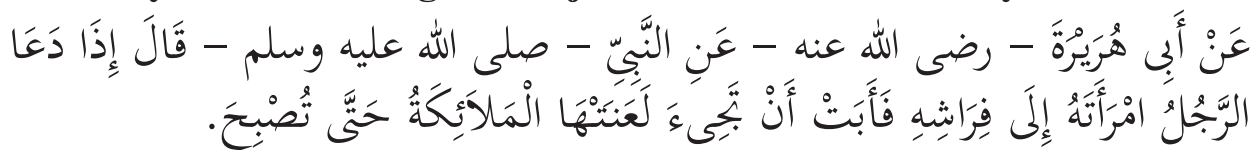

Dari Abu Hurairah RA dari Nabi SAW, beliau bersabda, "Apabila seorang lelaki mengajak istrinya ke tempat tidur lalu istrinya enggan untuk datang maka malaikat melaknatnya sampai ia berpagi hari." (HR. Al-Bukhari)

Pada Hadis tersebut menunjukkan tugas dan kewajiban istri yang paling utama adalah melayani suaminya sebagai bidadari di ranjangnya. Kata 'tempat tidur' (firasy) adalah bentuk sindiran (kinayah) untuk kata 'berhubungan intim' (jima ). ${ }^{13}$ Tentu saja tugas domestik rumah tangga ini sangat penting karena ancaman atas pengabaian tugas ini adalah dilaknat oleh malaikat atau mendapatkan kutukan dari malaikat sampai waktu pagi. Padahal, dengan melaksanakan tugas ini ia telah membantu suaminya untuk terhindar dari melampiaskan nafsunya pada yang haram atau zina. Oleh karena itu, hal ini harus menjadi perhatian utama wanita muslimah di rumahnya.

\section{Merawat anak-anak dengan baik}

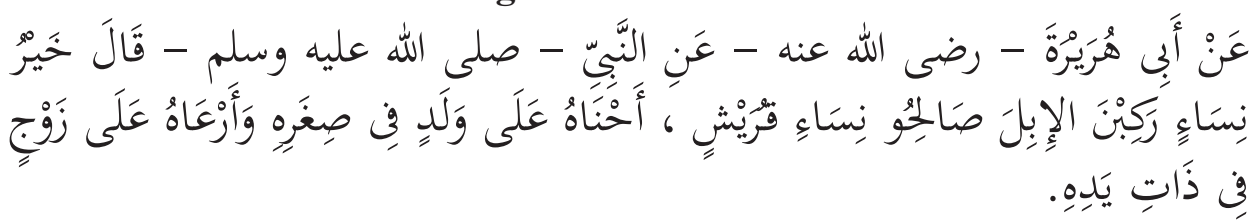

Dari Abu Hurairah RA dari Nabi SAW bersabda, "Sebaik-baik-baik wanita yang menunggang unta adalah wanita Quraish yang baik, yang paling lembut bagi anak pada masa kecilnya dan yang paling baik memelihara hak-hak suaminya." (HR. Bukhari, Muslim dan Ahmad)

Wanita muslimah dituntut untuk lemah-lembut dan cinta pada anakanaknya dalam merawat anak-anaknya yang masih kecil apalagi jika anaknya yatim. ${ }^{14}$ Wanita punya peranan membentuk generasi yang baik dan sehat sementara suaminya bekerja mencari nafkah. Inilah salah satu tugas wanita dalam rumah tangga yang sangat penting. Wanita muslimah juga dituntut untuk memelihara hak-hak dan amanah suami pada hartanya serta mengatur dan melindungi uang nafkah yang telah diberikan. ${ }^{15}$

13 Ahmad bin 'Ali bin Hajar al-'Asqalani, Fath al-Bari Sharah Sahih aL-Bukhari, Jil. 9 (Beirut: Dar al-Ma'rifah, 1379 H), hlm. 294

14 Abu Zakariyya Yahya bin Sharaf an-Nawawi, Al-Minhaj Sharah Sahih Muslim bin Hajjaj, Cet. 2, Jil. 16 (Beirut: Dar Ihya’ at-Turath al-'Arabi, 1392H), hlm. 80 15 Ibid. 


\section{Menjaga kebersihan kamar mandi dan ruangan di rumah}

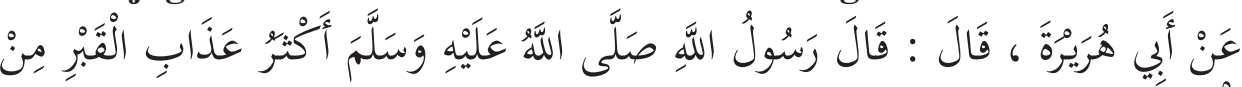
الْبوَلِن.

Dari Abu Hurairah berkata, Rasulullah SAW bersabda, "Kebanyakan azab kubur karena air kencing." (HR. Al-Hakim)

Menjaga kebersihan kamar mandi adalah hal penting yang harus diperhatikan, karena hal ini berhubungan dengan kenyamanan penghuni rumah jika bau yang ditimbulkan tidak sedap. Selain itu, hal ini juga menyebabkan seseorang tertimpa azab kubur karena meninggalkan sikap berhati-hati terhadap bekas kencing. ${ }^{16}$ Seorang wanita muslimah harus berhati-hati dan memperhatikan kebersihan kamar mandi agar najis tidak menyebar ke dalam rumah.

Selain itu jika ada tempat yang terkena najis pada ruangan lainnya juga harus segera dibersihkan setelah selesai buang hajat. Rasulullah SAW pernah bersabda tentang orang yang buang air sembarangan karena ketidaktahuannya.

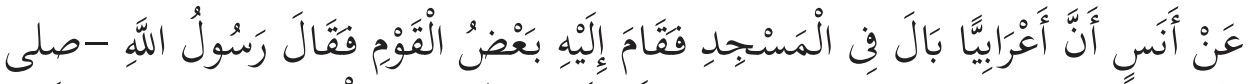

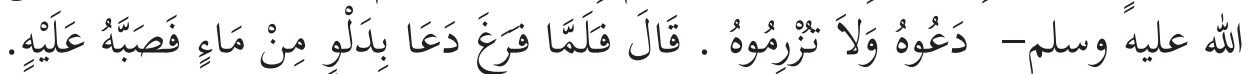

Dari Anas, bahwa seorang laki-laki Arab kencing di masjid, lalu sebagian kaum mendatanginya maka Rasulullah SAW bersabda, "Biarkan dia, jangan dicegat." Anas berkata, "Ketika dia selesai (kencing) beliau meminta dibawakan seember air, lalu beliau siram ke atas kencing itu." (HR. Muslim)

Hadis ini menunjukkan kepada kita bahwa jika ada najis hendaknya dibersihkan dengan segera setelah najis itu selesai dikeluarkan. Ini untuk mencegah terdapatnya najis di dalam masjid. Jika membersihkan najis di tempat kita beribadah yang hanya sebentar saja kita tempati adalah ajaran Sunnah, maka membersihkan najis di tempat kita tinggal adalah lebih utama. Hal ini juga berhubungan dengan kebersihan tempat kita tinggal. Adapun najis yang mungkin dapat terjadi di dalam rumah adalah najisnajis karena anak-anak kecil, binatang ternak, binatang peliharaan dan binatang pengganggu.

\section{Mengurus kain-kain yang kotor}

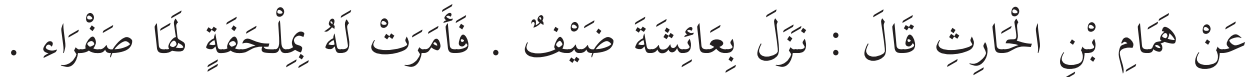

16 Muhammad Shams al-Haqq al-'Azim Ābadi, 'Aun al-Ma'bud Sharah Sunan Abi Dawud, Cet. 2, Jil. 1 (Beirut: Dar al-Kutub al-'Ilmiyyah, 1415H), hlm. 27 


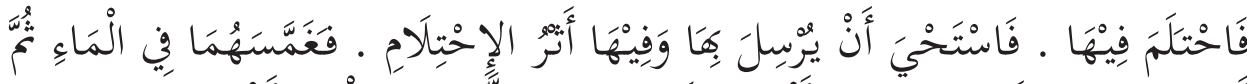

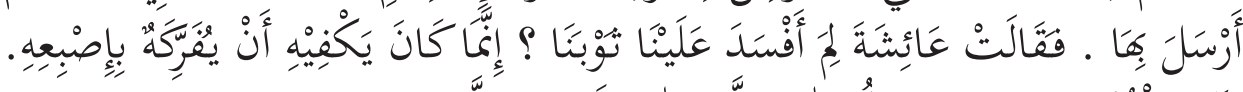

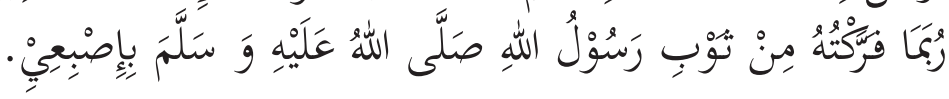

Dari Hammam bin al-Harith dia berkata, "'Aisyah didatangi tamu. Lalu beliau memerintahkan memberi tamunya selimut milik beliau yang warna kuning. Ternyata tamunya mimpi basah dan dia malu mengembalikan selimut yang ada bekas mimpi basahnya. Lalu tamu itu mencelupkannya ke dalam air kemudian dia kembalikan selimutnya. Lalu 'Aisyah berkata, "Kenapa dia merusak pakaian kami? Cukuplah baginya menggosoknya dengan jarinya saja. Boleh jadi aku menggosok pakaian Rasulullah SAW dengan jariku. " (HR. At-Tirmizi, Ibnu Majah dan Ahmad)

Hadis ini menunjukkan bahwa para istri Nabi terbiasa mencuci langsung pakaian mereka juga pakaian Rasulullah. Sehingga pakaian kotor tidak menumpuk di dalam rumah. Pakaian yang mudah dibersihkan tidak perlu direndam. Ini juga menjadi hal yang harus diperhatikan di dalam urusan domestik rumah tangga. Di samping itu Rasulullah pernah langsung membersihkan pakaian yang terkena najis.

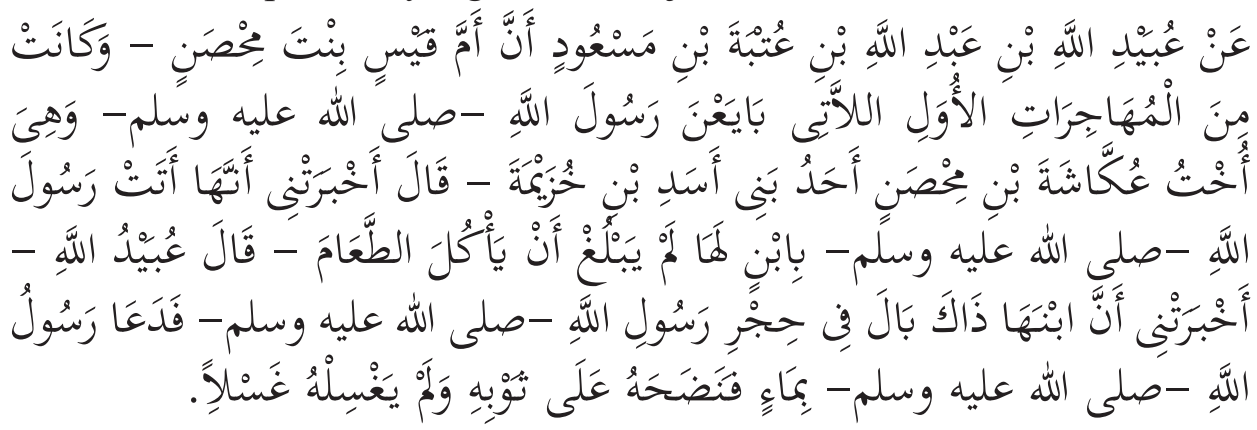

Dari 'Ubaidillah bin 'Abdullah bin 'Utbah bin Mas' 'ud bahwa Ummu Qais binti Mihsan - beliau dahulu adalah termasuk para sahabiah yang berhijrah hijrah pertama yang berbaiat dengan Rasulullah $S A W$ - dan beliau adalah saudara perempuan 'Ukkasyah bin Mihsan, salah seorang Bani Asad bin Khuzaimah. 'Ubaidillah berkata, "Dia (Ummu Qais) mengabarkan padaku bahwa dia datang pada Rasulullah SAW dengan membawa anaknya yang belum makan makanan (selain ASI)," - 'Ubaidillah berkata - bahwa anaknya itu kencing di hujrah (kamar) Rasulullah sallallahu 'alaihi wa sallam maka Rasulullah SAW meminta dibawakan air lalu beliau memercikkannya ke atas bajunya dan tidak membilasnya sekalipun. (HR. Muslim) 
Dari Hadis di atas, dapat kita ambil pelajaran bahwa membersihkan pakaian kotor atau bernajis sebaiknya dilakukan sesegera mungkin agar pakaian lebih mudah dibersihkan sehingga tidak merusak baju dan tidak menyebabkan bau dan kuman penyakit. Hal ini juga berlaku sama agar membiasakan untuk menyimpan pakaian yang sudah dicuci sesegera mungkin dan menyimpan di tempat yang aman.

\section{Membereskan dapur}

عَنْ جَابِرِ بْنِ عَبْدِ اللَّهِ - رضى الله عنهما - يَقُولُ قَالَ رَسُولُ اللَّهِ - صلمى الله عليه

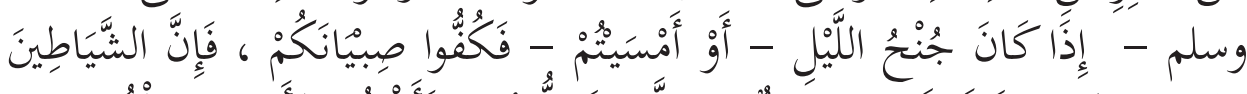

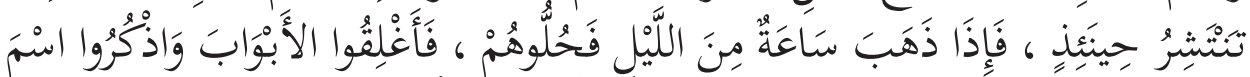

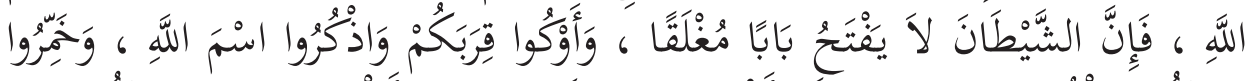

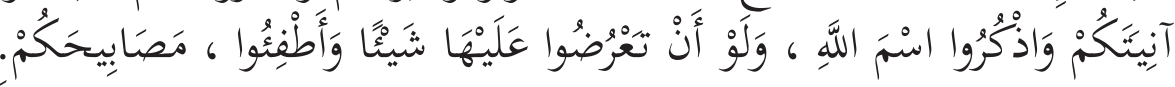

Dari Jabir bin 'Abdullah RA dia berkata, Rasulullah SAW bersabda, "Apabila masuk waktu malam - atau kalian di sore hari-, "Tahanlah balita kalian, sungguh syaitan menyebar pada waktu itu. Lalu jika telah berlalu satu jam lepaskan mereka. Dan tutuplah pintu-pintu dan sebutlah nama Allah. Sungguh syaitan tidak dapat membuka pintu yang ditutup. Dan tutuplah tempayan air dan sebutlah nama Allah. Dan tutuplah piringpiring makan kalian dan sebutlah nama Allah. Meskipun hanya dengan meletakkan sesuatu di atasnya. Dan matikanlah lampu-lampu kalian.' (HR. Bukhari, Muslim, At-Tirmizi)

Hal yang tak luput dari pengawasan wanita muslimah di rumah adalah membereskan dapur setelah makan. Dalam ajaran Sunnah kita diperintahkan untuk menutup tempat minum dan tempat makan kita sambil menyebut nama Allah. Hal ini untuk mencegah syaitan makan dan minum di rumah kita dan tinggal di dalamnya. Rasulullah telah mengingatkan pentingnya berlindung dari gangguan syaitan dengan cara ini. Selain itu menutup makanan dan minuman juga dapat menghindarkan manusia dari terkena wabah penyakit. Hadis ini menunjukkan berkumpulnya kebaikan, adab dan kemaslahatan untuk dunia dan akhirat. ${ }^{17}$

\section{Mengatur menu makanan yang baik}

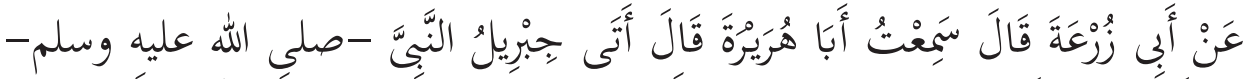

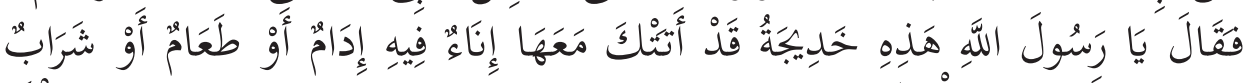

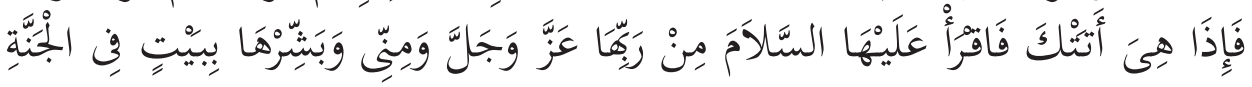




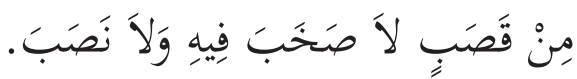

Dari Abu Zur'ah berkata, Aku mendengar Abu Hurairah berkata, "Jibril mendatangi Nabi SAW dan berkata, 'Wahai Rasulullah, ini adalah Khadijah sungguh ia menuju padamu dengan talam yang di dalamnya ada lauk atau makanan atau minuman (ini dari keraguan perawi, pen.). Apabila dia telah datang bacakanlah untuknya salam dari Tuhannya 'Azza wa Jalla dan dariku. Dan berilah kabar untuknya dengan sebuah rumah di surga yang tiada suara teriakan di dalamnya dan tidak pula lelah.'” (HR. Muslim)

Pada Hadis di atas menunjukkan kemuliaan seorang istri di sisi Allah yang senantiasa ikhlas dengan penuh cinta menyajikan hidangan untuk suaminya. Allah 'Azza wa Jalla dan Malaikat Jibril 'alaihissalam yang merupakan pimpinan para malaikat memberikan salam untuknya dan memberi kabar gembira untuknya dengan surga yang tiada kelelahan dan penat di dalamnya. Rumah itu terbuat dari mutiara yang sangat indah namun bentuknya seperti istana yang megah. ${ }^{18}$ Inilah yang menjadi teladan dan motivasi bagi wanita muslimah untuk meraih surga Allah melalui rutinitas memasak.

Selain itu, Rasulullah biasa diberikan madu dan juga makanan manis oleh istrinya bila beliau pulang.

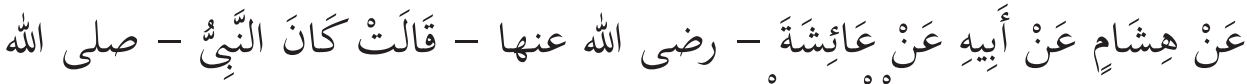

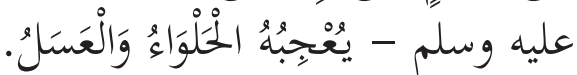

Dari 'Hisyam, dari ayahnya, dari 'Aisyah radiyallahu 'anhuma beliau berkata, "Dahulu Nabi SAW, makanan manis dan madu membuat beliau sangat senang." (HR. Al-Hakim)

Jika kita kaitkan dengan zaman sekarang wanita muslimah dapat menyiapkan snack untuk suami bersantai di rumah. Tersedianya makanan manis dan juga madu di rumah sangat baik jika suami baru tiba di rumah karena terkadang mereka pulang dengan rasa letih dan merasa lapar.

Selain makanan, snack dan madu, wanita muslimah juga dapat menyajikan susu.

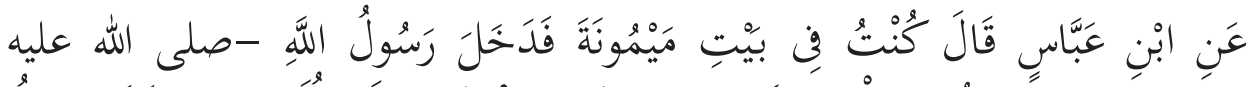

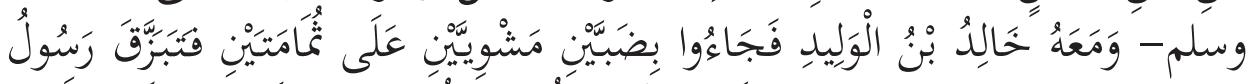

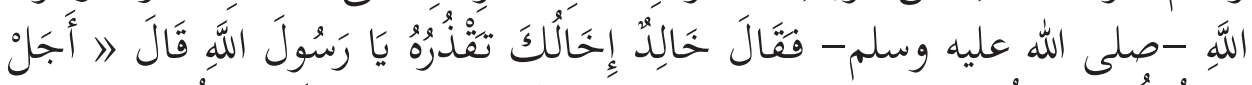

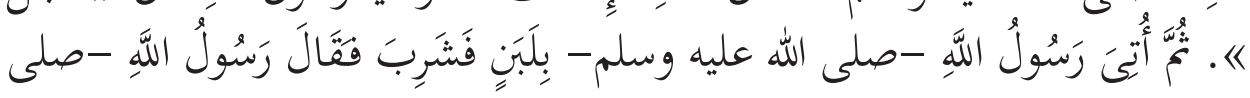

18 Abu Zakariyya, Al-Minhaj, Jil. 15, hlm. 199 


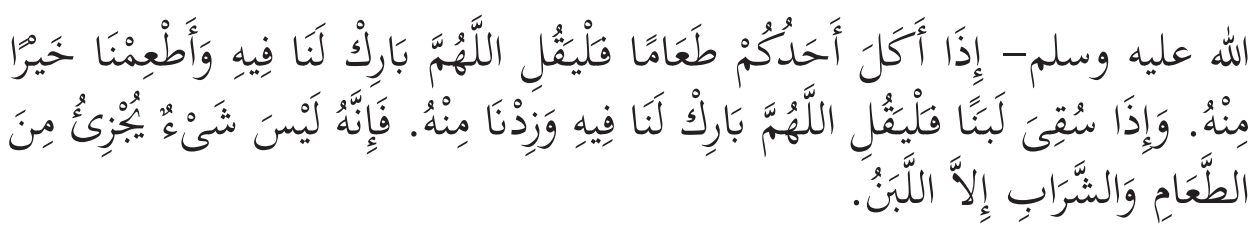

Dari Ibnu 'Abbas beliau berkata, "Aku pernah di rumah Maimunah lalu Rasulullah SAW masuk ke rumah dan bersama beliau ada Khalid bin Walid. Mereka datang dengan dua ekor biawak panggang di atas dua wadah. Lalu Rasulullah SAW bersandar. Khalid berkata, 'Engkau membiarkannya (tidak memakannya) wahai Rasulullah?' Beliau menjawab 'Ya. 'Kemudian Rasulullah SAW diberi susu lalu beliau minum dan Rasulullah SAW bersabda, 'Apabila seorang di antara kalian makan, hendaklah ia berdoa ya Allah berkatilah kami di dalamnya dan berilah kami makanan yang lebih baik daripadanya. Dan Apabila diberi minum hendaklah ia berdoa ya Allah berkatilah kami di dalamnya dan tambahkanlah untuk kami daripadanya. Sungguh tiada sesuatupun makanan dan minuman yang sebanding dengan susu. ", (HR. Abu Daud)

Pada Hadis di atas istri Rasulullah menyajikan susu untuk beliau yang baru datang. Susu dikenal sebagai minuman terbaik bagi manusia karena di dalamnya terdapat banyak mineral dan vitamin yang sangat penting bagi tubuh. Susu juga minuman yang diberkahi karena Nabi mendoakan keberkahan padanya.

\section{Mencegah adanya sarang binatang yang merusak rumah}

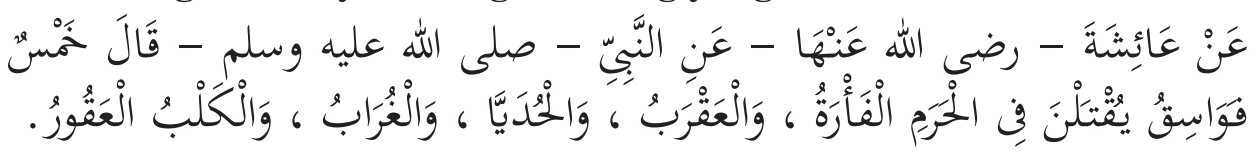

Dari 'Aisyah radiyallahu 'anha dari Nabi SAW beliau bersabda, "Lima binatang fasiq yang boleh dibunuh di tanah Haram adalah tikus, kalajengking, burung rajawali, burung gagak dan anjing buas." (HR.

Bukhari, Muslim, Abu Daud dan At-Tirmizi)

Dalam Hadis adalah hewan-hewan yang boleh dibunuh meskipun sedang berada di tanah Haram yaitu Mekkah. Hewan ini adalah hewan yang biasa ada di padang pasir. Kelima hewan ini diperintahkan untuk dibunuh karena menyakiti manusia. ${ }^{19}$ Tikus adalah hewan pengganggu yang biasa masuk ke dalam rumah. Tikus dapat memakan cadangan makanan kita, merusak barang, meninggalkan najis di rumah dan juga dapat menggigit manusia. Sangat penting merawat rumah dan membersihkannya serta mencegah masuk dan bersarangnya tikus dan hewan pengganggu lainnya

19 Abu Zakariyya, Al-Minhaj, Jil. 8, hlm. 115 
seperti nyamuk, lalat, cicak, laba-laba, semut dan lipas.

\section{Berdandan untuk suami, patuh padanya dan mendukungnya}

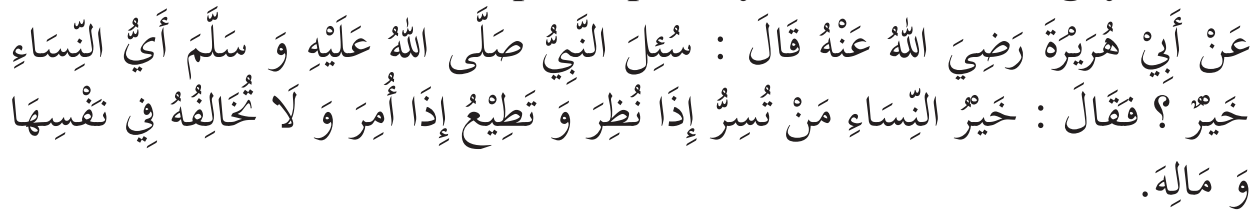

Dari Abu Hurairah radiyallahu 'anhu berkata, "Nabi sallallahu 'alaihi wa sallam ditanya, 'Seperti apa wanita yang terbaik?' Beliau lalu bersabda, 'Sebaik-baik wanita adalah yang menyenangkan jika dilihat, yang taat ketika diperintah, dan yang tidak menyelisihi (suami)nya pada diri dan hartanya."' (HR. Al-Hakim, An-Nasa'i, At-Tabrani dan Abi Hatim)

Hadis ini menunjukkan bahwa seorang wanita terbaik yang dimiliki oleh suami adalah yang dapat membuat suami senang melihatnya. Termasuk urusan domestik wanita adalah berdandan untuk suami. Selain itu wanita muslimah juga dituntut untuk patuh pada suaminya. Hal ini agar terjalin rasa cinta dan saling menghormati serta menciptakan atmosfer kehidupan yang sakinah di dalam rumah tangga.

Selanjutnya agar rumah tangga bahagia, maka wanita muslimah perlu mendukung dan menyesuaikan diri dengan keadaan, pendapat, kegemaran dan keinginan suaminya sehingga tidak menyelisihi suami dalam urusan mereka. Terlebih lagi jika pada suatu keadaan, suami tidak suka bila istri ikut ambil bagian dalam urusannya. Penyesuaian diri wanita muslimah menjadi penting untuk dipahami agar memudahkan terciptanya suatu amal dan terwujudnya cita-cita rumah tangga secara damai. Dengan demikian, diharapkan suaminya dapat bersenang-senang dengan dirinya.

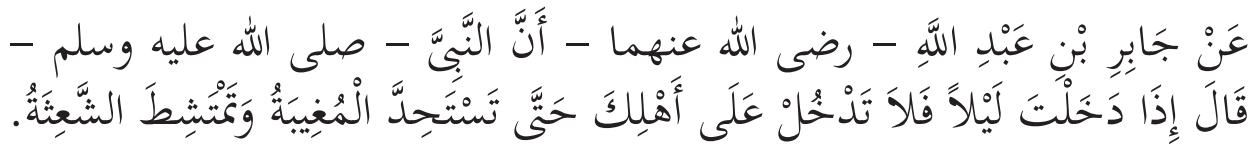

Dari Jabir bin 'Abdullah radiyallahu 'anhuma bahwa Nabi SAW bersabda, "Apabila engkau masuk di malam hari maka janganlah engkau masuk menemui istrimu sehingga wanita yang ditinggalkan itu mencukur bulu dan menyisir rambut yang masih acak-acakan.” (HR. Bukhari)

Pada hadis di atas menyiratkan bahwa wanita muslimah menyambut kedatangan suaminya dengan menyisir rambutnya dan mencukur bulu kemaluannya. Hal ini untuk memberikan penampilan terbaik untuk suaminya sehingga sedap dipandang. Di antara cara berhias juga adalah berpakaian yang rapi, dan memakai wewangian yang diperbolehkan serta selalu tunduk menjaga tutur katanya. Dengan demikian suami merasa 
senang, damai dan tentram karena di luar rumah banyak sekali godaan yang dihadapi suaminya. Selain itu wanita muslimah juga dapat berhias dengan Sunnah-sunnah fitrah yaitu bersiwak, memotong kuku, mencabut bulu ketiak, mencukur bulu kemaluan, istinja' yang bersih serta berkumurkumur.

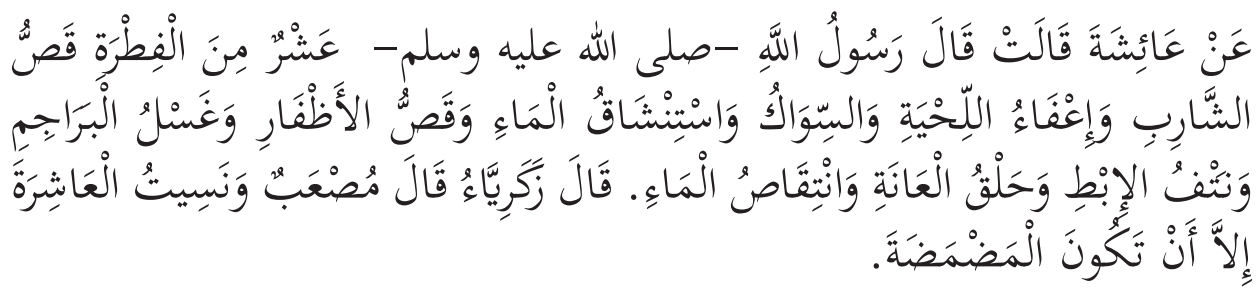

Dari 'Aisyah berkata, Rasulullah SAW bersabda, "Sepuluh dari fitrah: memotong kumis, mebiarkan janggut, bersiwak, memasukkan air ke hidung, memotong kuku, mencuci jemari, mencabut bulu ketiak, mencukur bulu kemaluan dan beristinja', Zakariya berkata, Mus 'ab berkata, "Aku lupa yang kesepuluh kalau tidak salah berkumur-kumur.” (HR. Muslim)

\section{Membereskan lampu tidur}

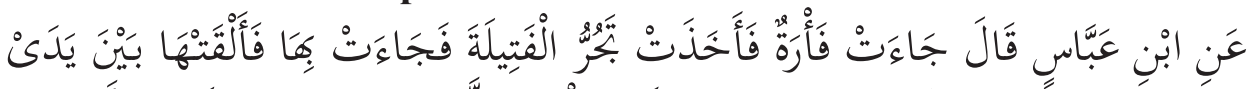

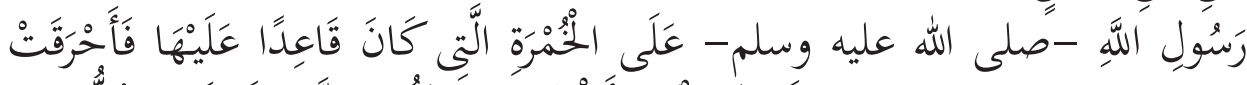

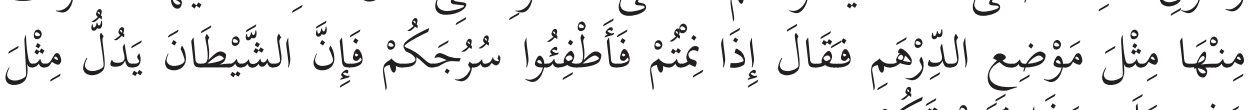

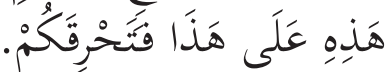

Dari Ibnu 'Abbas beliau berkata, "Seekor tikus datang, ia berlari di tali lampu minyak, lalu dia menyeretnya dan menjatuhkannya ketika Rasulullah SAW sedang duduk di tikar sajadah maka terbakarlah seukuran uang dirham, lalu beliau bersabda, 'Jika kalian tidur matikanlah lampulampu kalian, sungguh syaitan membimbing hewan yang seperti ini maka dia membakar kalian." (HR. Abu Daud, Al-Hakim, Al-Baihaqi dan Ibnu Hibban)

Di antara urusan domestik rumah tangga adalah mematikan lampu sebelum tidur. Hal ini untuk mencegah terjadinya kebakaran di dalam rumah yang dapat membinasakan harta bahkan nyawa. Ini juga merupakan bentuk berlindung dari gangguan syaitan di malam hari.

\section{Mendekorasi ruangan rumah}

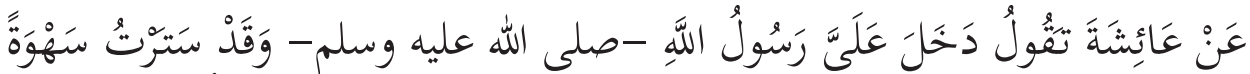

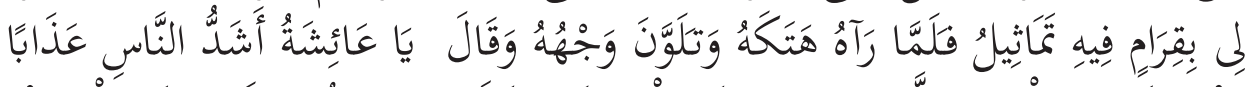

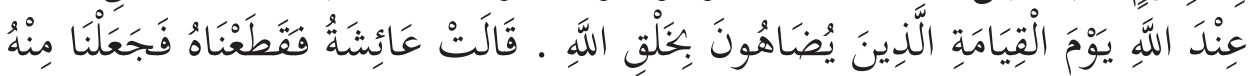




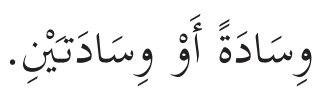

Dari 'Aisyah, beliau berkata, "Rasulullah SAW masuk ke rumahku. Sungguh aku telah memasang gorden kepunyaanku karena kelengahanku dengan gorden yang bergambar patung. Ketika beliau melihatnya beliau merusaknya dan wajahnya memerah. Beliau bersabda, 'Wahai 'Aisyah manusia yang paling berat siksanya di sisi Allah di hari kiamat adalah orang-orang yang meniru ciptaan Allah."' 'Aisyah berkata, "Lalu kami potong gorden itu dan kami jadikan satu atau dua bantal.” (HR. Muslim dan Abu Daud)

Dari Hadis di atas, wanita muslimah dibolehkan mendekorasi rumah dengan penataan perabot kecuali dengan yang haram seperti hiasan bergambar patung. Hal ini karena malaikat tidak masuk ke dalam rumah yang terdapat di dalamnya lukisan makhluk bernyawa. Hadis ini menunjukkan bahwa perbuatan melukis patung dan menjadikannya hiasan adalah perkara yang sangat dibenci Allah dan Rasul-Nya. Terlebih lagi jika lukisan itu membawa kepada syirik. ${ }^{20}$

\section{Menjaga agar suami tidak tertarik dengan wanita lain}

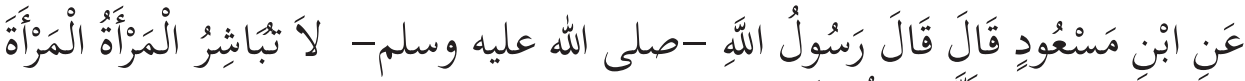

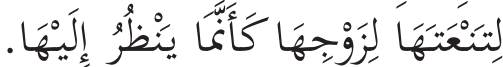

Dari Ibnu Mas 'ud berkata, Rasulullah SAW bersabda, "Janganlah seorang wanita bergaul dengan wanita lain untuk kemudian dia menggambarkannya kepada suaminya seakan-akan suaminya itu melihat langsung." (HR. Abu Daud)

Laki-laki diperintahkan Allah untuk menundukkan sebagian pandangan sehingga dapat menjaga kemaluannya. Dengan begitu mereka dapat merasa cukup (qana'ah) dengan istri dan tidak terjerumus kepada zina. Namun, ada wanita yang menyebutkan ciri-ciri dan sifat-sifat wanita lain kepada suaminya khususnya jika wanita itu cantik. Ia menggambarkan keadaan wanita itu sehingga suaminya seolah-olah melihat wanita itu. Bisa jadi suaminya menjadi punya keinginan (syahwat) pada wanita tersebut baik untuk menikahi wanita itu atau melakukan zina dengannya. Terlebih lagi jika dalam hatinya ada penyakit perzinaan. Hal ini jelas merugikan istri. ${ }^{21}$ Oleh karena itu, menceritakan wanita lain pada suami sangat dilarang dalam Islam. Dengan demikian, diharapkan mereka dapat fokus dengan

20 Ahmad bin 'Ali, Fath al-Bari, Jil. 10, hlm. 383

21 Syaikh Adnan Ath-Tharsyah, Menjadi Wanita Sukses dan dicintai (Jakarta: Pustaka Al-Kautsar, 2009), 156 
cinta antar suami istri tanpa kehadiran orang lain di keluarganya.

\section{Meminta izin jika keluar rumah}

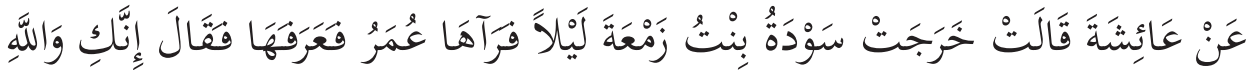

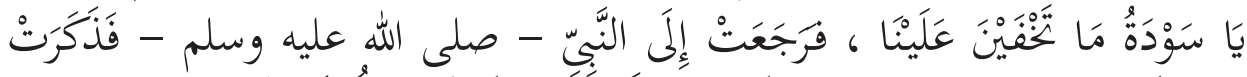

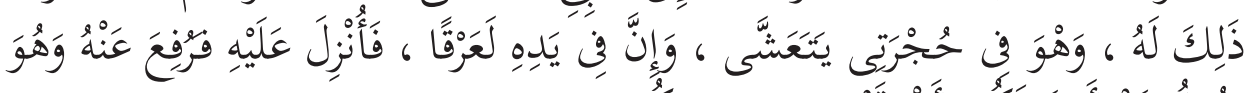

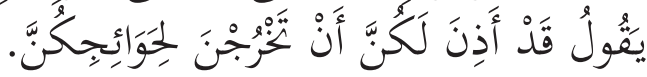

Dari 'Aisyah berkata, "Saudah binti Zam'ah keluar pada malam hari, lalu 'Umar melihatnya dan mengenalinya, ia berkata, 'Sungguh engkau adalah Saudah, kamu tidak bersembunyi dari kami.' Lalu Saudah balik kepada Nabi sallallahu 'alaihi wa sallam dan menyebutkan kejadian itu, dan beliau sedang di kamarku makan malam. Sungguh pada tangannya ada keringat maka turun kepadanya dan diangkat darinya. Lalu beliau bersabda, 'Sungguh telah aku ijinkan bagi kalian untuk keluar untuk keperluan-keperluan kalian.'

Hadis ini menunjukkan bahwa dalam Islam, wanita tidaklah dikurung di dalam rumah. Wanita muslimah boleh keluar dari rumah jika ada keperluan. Namun, keluarnya wanita harus mendapatkan ijin dari suaminya. Ini dipandang sebagai sebuah seni dalam rumah tangga untuk menghindari kecemburuan suami jika dia tidak ada di rumah juga agar tidak menimbulkan masalah yang baru nantinya. Meminta ijin adalah hal yang penting dalam rumah tangga.

\section{Bersedia untuk keturunan yang banyak}

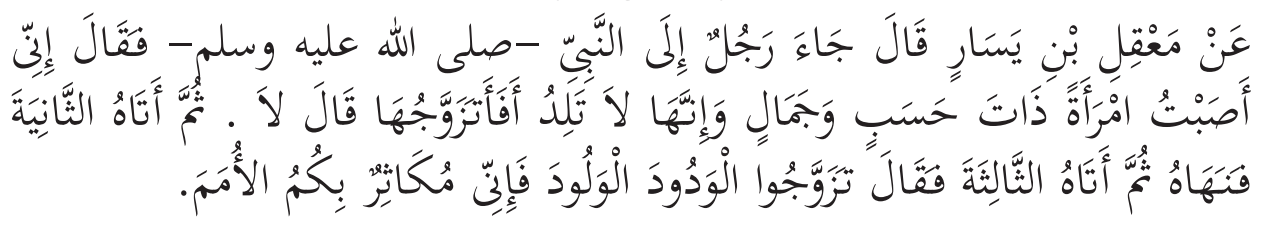

Dari Ma'qal bin Yasar berkata, Seorang lelaki datang Nabi SAW maka beliau bersabda, "Sungguh aku ingin menikah dengan seorang wanita yang memiliki kedudukan dan kecantikan, namun dia tidak bisa punya anak, apakah aku dapat menikahinya?" Beliau berkata, "Jangan." Kemudian ia mendatangi beliau yang kedua kalinya, beliau melarangnya. Kemudian ia mendatangi beliau yang ketiga kalinya, beliau bersabda, "Nikahilah wanita yang penuh cinta dan subur sungguh aku akan membanggakan kalian di kalangan umat-umat yang lain." (HR. Abu Daud, Al-Hakim, Al-Baihaqi)

Pada Hadis tersebut, Rasulullah memotivasi kita agar memiliki 
banyak keturunan agar umat Islam dapat menyebar di muka bumi untuk menyiarkan Islam sehingga akan menjadi kebanggaan Rasulullah atas umat-umat yang lain. Hal ini akan membawa kemuliaan di hari kiamat. Wanita yang menunda memiliki anak karena kuatir tubuhnya rusak perlu menyadari bahwa hamil, melahirkan dan menyusui anak adalah kodrat wanita yang tidak dapat dilakukan oleh lelaki. Oleh karena itu, hendaknya wanita muslimah bersedia untuk memiliki anak dan mempersiapkan kesehatan repoduksi agar selalu subur. Menjaga pola makan agar hormonhormon reproduksi selalu aktif dan dalam keadaan seimbang. Hal ini dapat dilakukan dengan aktivitas olah raga dan menjaga berat badan serta makan makanan yang bergizi seimbang dan sehat.

Keempat belas prinsip manajemen domestik rumah tangga wanita muslimah di atas tentunya adalah konsep dasar rutinitas harian rumah tangga yang menuntut adanya keteguhan hati, keikhlasan, dan kesabaran. Hal ini tentunya harus dipahami dengan baik karena dalam menjalani likaliku rumah tangga terkadang ada kondisi yang tidak dapat menuntaskan semua tugas tersebut. Namun, yang terpenting dari itu semua adalah sudah dikerjakan secara maksimal. Tentang hasilnya terpulang kepada kehendak Allah SWT. Allah berfirman,

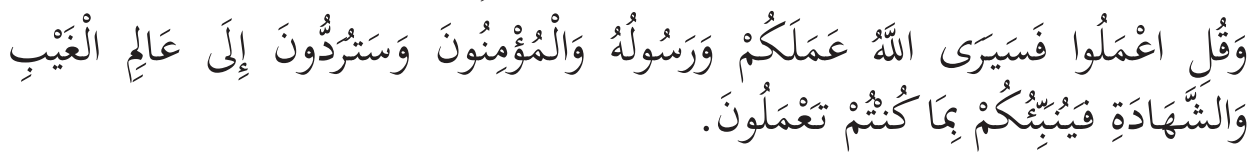

"Dan katakanlah olehmu (Muhammad), 'Beramallah kalian, maka Allah, Rasul-Nya dan orang-orang yang beriman akan melihat amalan kalian. Dan kalian akan dikembalikan kepada Yang Maha Mengetahui yang ghaib dan yang tampak maka Dia akan memberitahukan apa yang dahulu kalian kerjakan."' (QS. At-Taubah: 105)

Pada ayat di atas kita hanya diperintahkan untuk beramal sesuai kemampuan. Kita hanya dituntut untuk beramal dengan amal apapun secara maksimal dan konsisten. Allah, Rasul-Nya, dan orang-orang yang beriman akan menjadi saksi di akhirat untuk wanita muslimah tentang amalan di dalam rumah tangganya untuk kemudian diberikan balasannya. ${ }^{22}$ Dengan demikian, selalu berharap pahala dari sisi Allah karena Allah saja yang mampu membalas amal kebaikan seseorang.

\section{Simpulan}

Urusan domestik rumah tangga adalah tugas pokok wanita

22 Jalal al-Din Muhammad bin Ahmad al-Mahalli, Jalal al-Din 'Abd al-Rahman bin Abi Bakr al-Suyuti, Tafsir al-Jalalain, Cet. 1, Jil. 1, (Kairo: Dar al-Hadith, t.t), hlm.260 
muslimah di dalam rumah tangga. Hal ini karena wanita adalah pemimpin di rumah suaminya dan akan dimintai pertanggungjawaban terhadap kepemimpinannya. Kajian ini telah menemukan ada dua puluh Hadits yang berkaitan dengan manajemen domestik rumah tangga. Hadis-hadis ini merupakan Hadis yang sahih sehingga dapat menjadi landasan hukum syariat bagi wanita muslimah untuk menjalankan manajemen domestik rumah tangganya.

Dari kedua puluh Hadis-hadis di atas telah disimpulkan ada empat belas prinsip dasar dalam manajemen domestik rumah tangga wanita muslimah yang meliputi: mencintai mengurus rumah tangga; melayani suami dengan menjadi bidadari di rumahnya; merawat anak-anak dengan baik; menjaga kebersihan kamar mandi dan ruangan di rumah; mengurus kain-kain yang kotor; membereskan dapur; mengatur menu makanan yang baik; mencegah adanya sarang binatang yang merusak rumah; berdandan untuk suami, patuh padanya dan mendukungnya; membereskan lampu sebelum tidur di malam hari; mendekorasi ruangan rumah; menjaga agar suami tidak tertarik dengan wanita lain; meminta ijin jika keluar rumah dan bersedia untuk berketurunan yang banyak.

Tugas-tugas yang sederhana namun sangat banyak ini sebenarnya dapat dikerjakan dengan hati yang lapang. Hal ini mengingat pekerjaan ini adalah rutinitas yang tidak ada habisnya. Namun demikian, diharapkan rutinitas ini dapat membawa wanita muslimah kepada surganya Allah yang tiada kebisingan dan rasa penat di dalamnya.

\section{DAFTAR PUSTAKA}

Al-Qur'an Al-'Azim.

Ābadi, Muhammad Shams al-Haqq al-'Azim, 'Aun al-Ma'bud Sharah Sunan Abi Dawud, Beirut: Dar al-Kutub al-'Ilmiyyah, 1415.

Al-'Asqalani, Ahmad bin 'Ali bin Hajar, Fath al-Bari Sharah Sahih aLBukhari, Beirut: Dar al-Ma'rifah, 1379.

Al-Mahalli, Jalal al-Din Muhammad bin Ahmad, dan Jalal al-Din 'Abd al-Rahman bin Abi Bakr al-Suyuti, Tafsir al-Jalalain, Kairo: Dar alHadith, t.t.

Ambarwati, Dwi Retno Sri, Antara Desain Interior Dan Dekorasi Interior Sebuah Kajian Komparatif, Jurnal Pengetahuan \& Perancangan Desain Interior, Vol. 2/No. 3/Desember/2012, (53-62).

An-Nawawi, Abu Zakariyya Yahya bin Sharaf, Al-Minhaj Sharah Sahih Muslim bin Hajjaj, Beirut: Dar Ihya’ at-Turath al-'Arabi, 1392.

Ath-Tharsyah, Syaikh Adnan, Menjadi Wanita Sukses dan dicintai, Jakarta: 
Pustaka Al-Kautsar, 2009.

al Kajian Gender dan Anak, Vol.12/No.01/Juni/2017, (77-88).

Junaidi, Heri. "Ibu Rumah Tangga: Streotype Perempuan Pengangguran." An Nisa'a 12, no. 1 (2017): 77-88.

Majma' al-Lughah al-'Arabiyyah, Al-Mu'jam al-Wajiz, Republik Arab Mesir: Kementerian Pendidikan dan Pengajaran, 2003.

Pusat Bahasa, Kamus Bahasa Indonesia, Jakarta: Pusat Bahasa Departemen Pendidikan Nasional, 2008.

Putri, Dyah Purbasari Kusumaning, and Sri Lestari. "Pembagian Peran Dalam Rumah Tangga Pada Pasangan Suami Istri Jawa." Jurnal Penelitian Humaniora 16, no. 1 (2015): 72-85. http://journals.ums. ac.id/index.php/humaniora/article/view/1523/1056 2006.

Retno Sri Ambarwati, Dwi. "Antara Desain Interior Dan Dekorasi Interior Sebuah Kajian Komparatif." LINTAS RUANG: Jurnal Pengetahuan \& Perancangan Desain Interior 2, no. 3 (2012).

Sunarmi. "Pendekatan Pemecahan Desain Interior Rumah Tinggal." ORNAMEN 10, no. No. 1 (2013): 41-56. 